\title{
New Light on the Silent Millennia: Mediterranean Africa, ca. $4000-900$ BC
}

\author{
Giulio Lucarini (iD) Y Youssef Bokbot • Cyprian \\ Broodbank
}

Accepted: 8 September 2020 / Published online: 27 October 2020

(C) The Author(s) 2020

\begin{abstract}
The so-called neolithization process (ca. 6000/5500-4000 BC) in Mediterranean Africa and the Sahara has been increasingly researched in recent years. In contrast, relatively little is known, especially in Mediterranean Africa, of the period between the beginnings of irreversible climatic deterioration in the Sahara, around $4000-3500 \mathrm{BC}$, and the onset of Iron Age to broadly Classical times. Why, with the exception of the Nile Delta, is our knowledge of the period between the fourth millennium BC and the threshold of the first Iron
\end{abstract}

\section{G. Lucarini $(\bowtie)$}

Institute of Heritage Science (ISPC), National Research Council of Italy (CNR), Area della Ricerca di Roma 1, Montelibretti, Rome, Italy

e-mail: giulio.lucarini@cnr.it

G. Lucarini

Department of Asian, African and Mediterranean Studies,

University of Naples L'Orientale, Naples, Italy

G. Lucarini $\cdot$ C. Broodbank

McDonald Institute for Archaeological Research, University of Cambridge, Cambridge, UK

\section{G. Lucarini}

International Association for Mediterranean and Oriental Studies (ISMEO), Rome, Italy

\section{Y. Bokbot}

Institut National des Sciences de l'Archéologie et du Patrimoine (INSAP), Rabat, Morocco

\section{Broodbank}

Department of Archaeology, University of Cambridge,

Cambridge, UK
Age Phoenician and Greek colonies so limited? To what extent can this information gap be attributed to aridification in the Mediterranean zone, or is it rather a product of the failure to look for the right kinds of materials and sites, and of their relative visibility? In order to answer these questions, this paper focuses specifically on Mediterranean Africa (with the exception of Egypt) from about $4000 \mathrm{BC}$ to ca. $900 \mathrm{BC}$. It is mainly based on the data made available on MedAfriCarbon, a spatially linked, publicly accessible database and web app comprising the $14 \mathrm{C}$ chronometric evidence from Mediterranean Africa from 12,000 to $600 \mathrm{cal}$. BC, with details of associated cultural and economic information. Analysis of these data shows that most of Mediterranean Africa beyond the Nile was occupied to different extents throughout the 3000-year period covered in this article and that, with a few important exceptions, the robust and resilient nature of local, mainly pastoral, ways of life militated against a shift towards a fully agricultural economy.

Résumé Le processus dit de néolithisation (environ 6000/5500-4000 avant J.-C.) en Afrique méditerranéenne et au Sahara a fait l'objet de recherches plus approfondies ces dernières années. En revanche, relativement peu de choses sont connues en Afrique méditerranéenne sur la période comprise entre le début de la détérioration irréversible du climat au Sahara, vers 4000-3500 avant J.-C., et le début de l'âge du fer jusqu'aux période classiques. Pourquoi, hormis pour le delta du Nil, notre connaissance de la période comprise entre le quatrième millénaire avant J.-C. et le début de 
l'âge du fer phénicien et grec colonial est-elle si limitée? Dans quelle mesure ce manque d'information peut-il être attribué à l'aridification de la zone méditerranéenne? $\mathrm{Ou}$ résulte-t-il plutôt du manque de recherche d'évidences archéologiques et de sites significatifs, ainsi que de leur visibilité relative? Pour répondre à ces questions, cet article se concentre particulièrement sur l'Afrique méditerranéenne (hormis l'Égypte), autour de 4000 à 900 avant J.-C. Cette étude se fonde principalement sur les données produites par la base de donnée géolocalisée accessible au public MedAfriCarbon et une application web comprenant des données chronométriques $14 \mathrm{C}$ provenant d'Afrique méditerranéenne de 12000 à $600 \mathrm{cal}$. avant J.-C., comprenant le détail des données culturelles et économiques associées. Une analyse de ces données montre que la plus grande partie de l'Afrique méditerranéenne a été occupée à des degrés divers durant cette période de 3000 ans et que, à quelques exceptions notables et souvent tardives, la nature robuste et résiliente des modes de vie locaux principalement pastoraux au-delà du Nil, a milité contre une évolution vers une économie entièrement agricole.

Keywords Mediterranean Africa $\cdot$ Mid- to late

Holocene $\cdot$ Radiocarbon dates $\cdot$ Pastoralism $\cdot$ Agriculture

\section{Introduction}

It is a perverse truth of North African prehistory, beyond the Nile corridor, that its final millennia are also its least known and understood. Nowhere is this more true than in Mediterranean Africa, defined as the elongated ribbon of land 300-500 km deep that stretches from Atlantic
Morocco to the isthmus of Suez (Fig. 1). The archaeology of this zone has recently been the subject of a twoyear research project, MedAfrica: Archaeological deep history and dynamics of Mediterranean Africa, ca. 9600-700 BC, which aims to create an up-to-date interpretative synthesis of the overall Holocene dynamics, up to the early first millennium BC. MedAfrica focuses on this zone not merely because its little-understood internal patterning is of intrinsic interest, but also in the belief that a deeper time appreciation of its role as a connecting zone or buffer between the societies and networks of Saharan and sub-Saharan Africa, on the one hand, and the Mediterranean world, on the other, may help us to understand and better contextualize the later long-term history of interaction between these regions (Broodbank and Lucarini 2019 for the overall results of this research initiative).

This paper focuses specifically on Mediterranean Africa over the last three millennia (ca. 4000-900 BC) before the arrival of Iron Age Phoenician and later Greek colonists and connections. Although the remit of MedAfrica as a whole fully includes the Nile Delta and adjacent areas within its purview, Egypt is not covered here, because Egypt's Pre-Dynastic and Dynastic archaeology, from the fourth to first millennia BC, is already well known. But beyond the Nile corridor, this situation is reversed: we know far more about the earlier Holocene societies of Mediterranean Africa than their later Holocene successors. In part, this is a result of the wider interest in issues of agricultural and pastoral emergence, the endurance of hunting, gathering and foraging, and combinations of these ways of life, the temporal focus of which tends to be early to mid-Holocene in this part of the world. This is exemplified by renewed excavations at Haua Fteah in

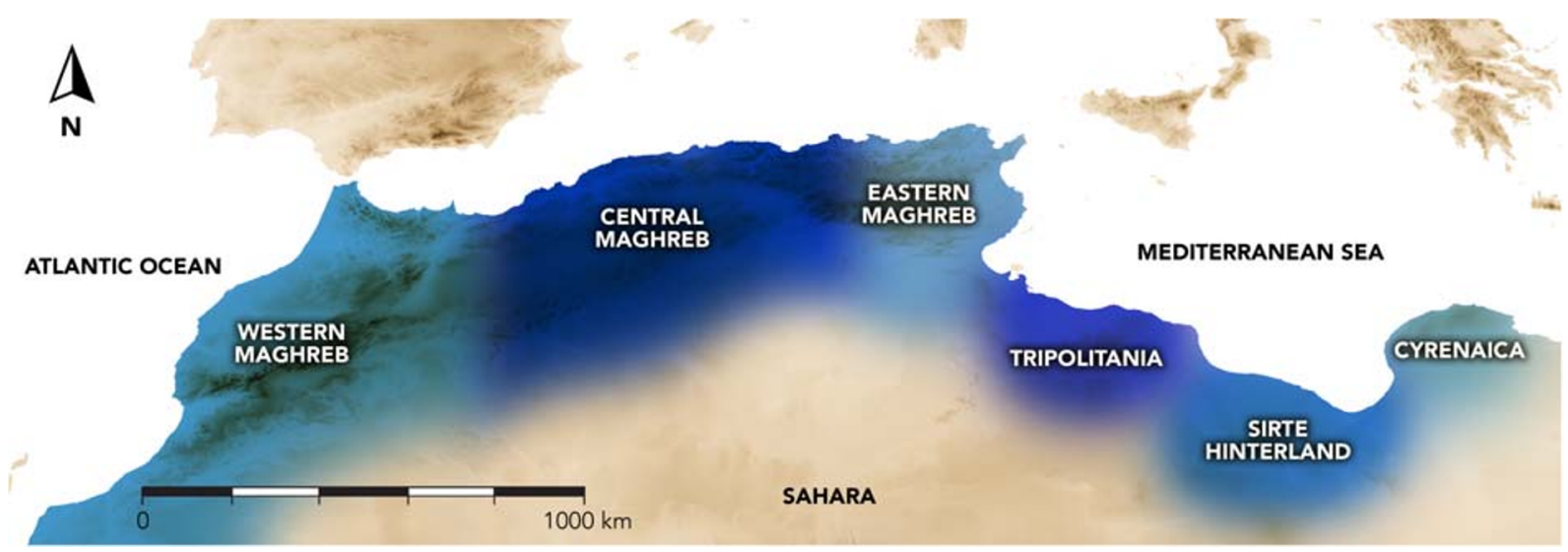

Fig. 1 Mediterranean Africa with the regions mentioned in the text (modified after Broodbank and Lucarini 2019) 
Libya (Barker et al. 2008, 2009, 2010, 2012), Hergla SHM-1 in Tunisia (Mulazzani 2013), Ifri Oudadane, and other new sites in Morocco (Linstädter 2008; Linstädter and Kehl 2012; Linstädter et al. 2016b), as well as groundbreaking work in the neighboring Sahara (Barich et al. 2014; Dunne et al. 2012; Garcea 2006; Mercuri et al. 2018; Wendorf et al. 2001). This lacuna is also encouraged by an early Holocene "Epipalaeolithic" overspill effect from North African Pleistocene archaeology, whose importance in terms of human evolution has long been recognized and is newly fortified by finds at Jebel Irhoud (Hublin et al. 2017). As a consequence, and in contrast to the abundant questions articulated for the contemporary Copper and Bronze Age Mediterranean to its north (Broodbank 2013, p. 257-505), the archaeology of Mediterranean Africa 4000-900 BC so far lacks a strong agenda of its own. We propose such an agenda by beginning to synthesize what we do and do not know about this elusive period. We shall avoid chronological labels brought in from the European side of the Mediterranean, including various "Neolithics," and in particular "Bronze Age" and "Protohistoric," and instead restrict ourselves to the main attributes apparent over time, using an approximate half-millennial radiocarbon-based framework. Beyond informational gapfilling, we argue that this last phase in Mediterranean Africa's prehistory matters for two reasons.

First, it should hold answers to what happened over the long-term to the first influxes of ultimately Levantine-European agriculture that did appear, whether in initially disaggregated or packaged forms, within a few centuries of each other during the mid-to-late sixth millennium BC at opposite ends of Mediterranean Africa. The first happened in the Nile Delta and adjacent areas where farming consolidated over the later fifth millennium BC (Hawass et al. 1988; Holdaway and Wendrich 2017). The second, around Tangier and neighboring parts of northwest Morocco, was associated with the spread of farming into the westernmost end of the Mediterranean (Ballouche and Marinval 2003; Gibaja et al. 2012; Morales et al. 2013, 2016). Did these two bridgeheads subsequently expand along the intervening length of Africa's Mediterranean rim, as might be anticipated on the basis of the pattern across Mediterranean Europe? Or, save for expansion southward down the Nile, did domestic crops fail to take broader hold, in contrast to the manifest popularity from the sixth and fifth millennia BC onwards of herdingbased lifestyles (mainly utilizing introduced domestic sheep and goat; Gautier 2014; Linseele et al. 2014;
Vermeersch et al. 2015), as well as the growing palaeobotanical and stone tool-derived evidence for a tradition of intensive wild plant gathering both here and in the Sahara (Barker et al. 2008, p. 208-213; 2009, p. 83-88; 2010, p. 76-78; Dunne et al. 2016; Lucarini 2014; Lucarini and Radini 2020; Lucarini et al. 2016; Mercuri et al. 2018)? Although the palaeobotanical picture, whether of domestic crops or wild plants, remains bedeviled by a paucity of up-to-date systematic site sampling and analysis of macro-remains, the situation is gradually improving, and the absence or occasional presence of crops in specific regions over the millennia under investigation, and those immediately preceding them, is therefore becoming increasingly credible. If farming was indeed only patchily attested, this raises the intriguing question as to why it might have stalled, given the environmental similarities between much of Mediterranean Africa and the basin's northern and eastern rim, where over the same period agriculture took off dramatically. It is worth stressing at this juncture that although the three millennia under present discussion undoubtedly witnessed widespread aridification across both the Sahara and Mediterranean, only in the former zone was this severe enough to bring about abandonments or wholesale shifts in lifestyle (Drake et al. 2011; Kuper and Kröpelin 2006); in the latter, farming around much of the basin adapted but did not fail. Mediterranean Africa itself possesses an increasingly strong internal record of climatic and environmental change that points to the survival of dry but still essentially Mediterranean-type environments in most areas, with the exception of the low-lying, arid coastal strips running between the Maghreb and Cyrenaica, and then eastward to the Nile (Cheddadi et al. 1998; Giraudi et al. 2013; Hunt et al. 2011; Jaouadi et al. 2016).

Second, unless we can achieve a better understanding of the societies of Mediterranean Africa during this period, we will never attain a properly balanced knowledge of the background, context, and emergent dynamics of the early Iron Age experience in this part of Mediterranean Africa. At present, we have a little counterweight to, or indeed verification of, the first textual testimonies pertaining to the region. These testimonies were products of colonizing or external societies, and therefore difficult to evaluate as windows into indigenous ways of life. Egyptian references to the people to their west are thin and spatially ambiguous until the terminal second millennium $\mathrm{BC}$ (O'Connor 1990), while Herodotus' ethnohistory and intriguing claim of a division between pastoralists east of the Gulf of Syrte 
and farmers to the west date to several centuries after the first encounters and therefore require interrogation with independent information (Herodotus, The Histories, Book IV, 169-200). Without good archaeological data about local societies from the preceding and contemporary phases, the kinds of sophisticated analyses of the relations between indigenous and incoming people and ways of doing things, already undertaken for Iberia, France, and the Italian mainland and islands (as recently exemplified by numerous papers in Knapp and van Dommelen 2014) remain tantalizingly beyond our grasp for most of Mediterranean Africa.

\section{Data and Analysis}

The data for the last three thousand years of Mediterranean Africa's prehistory are exceptionally thin, scattered, riddled with lacunae, and short on long-term stratified sequences. One aim of this paper is to draw together, for the first time, the available information in a coherent form and more detail than has been possible before. Equally problematic, and a product of both poor typological definition of local material and the paucity of detailed stratigraphic sequences, is the difficulty in placing objects or horizons chronologically except with the aid of radiocarbon dates or other forms of scientific dating. Unfortunately, such chronometric data remain very few and unevenly distributed. These dates, together with all the geographical coordinates of the sites mentioned in this paper, are available on MedAfriCarbon, a spatially linked and publicly accessible database and web app of $14 \mathrm{C}$ chronometric evidence from Mediterranean Africa from 12,000 to $600 \mathrm{cal}$. BC, with associated economic and cultural attributes (https://theia.arch. cam.ac.uk/MedAfriCarbon), which has been deposited in Zenodo (https://doi.org/10.5281/zenodo.3630619) (Lucarini et al. 2020). Some 2000 publications have been trawled to obtain, and cross-check for data quality, the total of currently 1587 dates and associated contextual information held on this database, no less than 649 of which derive from Egyptian sites as far south as Fayum. Out of this grand total, and excluding Lower Egypt, only about 179 radiocarbon dates (slightly more than ten percent) from the remainder of Mediterranean Africa fall between ca. 4000 and 500 BC (dates with an error range equal or higher than \pm 250 have been counted and positioned in the maps, but not discussed in the text). To these 179 dates, we add two, published for the first time in this paper, from the remarkable site of Oued Beht in the low foothills of the Moroccan Middle Atlas.

This chronic imbalance in investigation and investment testifies to deep cultural and civilizational biases in favor of ancient Egypt, on a par with Emil Ludwig's infamous comment that "To the life of the Mediterranean, the [Athenian] Acropolis is more important than the whole history of Morocco» (1942, p. x). This modest nonEgyptian total of radiocarbon dates for the entire period investigated here breaks down regionally as follows: 87 from the Western Maghreb (corresponding to Morocco [84], including its Atlantic coast as far as Tarfaya and the hinterland up to the Atlas watershed, plus the Spanish enclave of Ceuta [3]); 24 from the Central Maghreb (the coastal and immediate hinterland regions of Algeria, roughly west of Constantine); 58 from the Eastern Maghreb (eastern Algeria [6] and Tunisia [52]); a mere seven from Libyan Tripolitania (effectively the Jebel Gharbi and Jefara plain); and just five from Libyan Cyrenaica. In chronological terms, these dates are spread broadly, but with a modest rise at the beginning of the third millennium $\mathrm{BC}$ and a drop in the mid/later second millennium BC. The ostensibly relatively healthy total for the Eastern Maghreb is mostly due to a late surge generated by efforts to date the early levels of Phoenician Carthage and contemporary sites. In general, such dating programs at Iron Age early colonial sites contribute to a notable spike in radiocarbon dates in the early first millennium $\mathrm{BC}$. In the region-by-region analysis that now follows (see Table 1; Fig. 2), the repeated emphasis on radiocarbon-dated phenomena simply reflects the fact that without such chronometric backing, even the basic placement of sites, materials, and other kinds of developments in time and historical trajectory will prove impossible to accomplish.

\section{Western Maghreb}

This region is the best-dated and documented sector of Mediterranean Africa over the timespan of this study, outside of Egypt. However, given the potential diversity of social, cultural, and economic dynamics at work here (including the posterity of an early farming enclave along the north coast, expansion from the southern interior by pastoralists, and perhaps the rise of complex communities in contact with Iberia), the current information is still spread very thin. The latest additions include eight radiocarbon dates, fourth to the first millennium $\mathrm{BC}$, from test excavations in the Oukkaïmedden valley $(3300-3600 \mathrm{~m}$ above sea level). These dates help to define the 
Table 1 The overall summary of 14C dates for each half-millennium (ca. 4000-500 BC), divided per region

\begin{tabular}{|c|c|c|c|c|c|c|}
\hline Time range (cal BC) & Western Maghreb & Central Maghreb & Eastern Maghreb & Tripolitania & Cyrenaica & Total \\
\hline $4000-3500$ & 14 & 4 & 9 & 2 & 1 & 30 \\
\hline $3500-3000$ & 16 & 4 & 3 & 1 & 1 & 25 \\
\hline Subtotal fourth millennium & 30 & 8 & 12 & 3 & 2 & 55 \\
\hline $3000-2500$ & 12 & 8 & 4 & 2 & 2 & 28 \\
\hline $2500-2000$ & 10 & 3 & 3 & 1 & 0 & 17 \\
\hline Subtotal third millennium & 22 & 11 & 7 & 3 & 2 & 45 \\
\hline $2000-1500$ & 20 & 3 & 4 & 0 & 0 & 27 \\
\hline $1500-1000$ & 7 & 0 & 2 & 0 & 0 & 9 \\
\hline Subtotal second millennium & 27 & 3 & 6 & 0 & 0 & 36 \\
\hline $1000-500$ & 8 & 2 & 33 & 1 & 1 & 45 \\
\hline TOTAL & 87 & 24 & 58 & 7 & 5 & 181 \\
\hline
\end{tabular}

chronology of early transhumant pastoral activity in the High Atlas for the first time (Rubinos 2014; Ruiz-Gálvez et al. 2013). Also significant are the two already mentioned above, out of a projected longer sequence of dates from Oued Beht in the low foothills of the Middle Atlas.

Well-documented activity during the early to midfourth millennium $\mathrm{BC}$ concentrates along the coast in the northeast, in the rockshelters of Ifri Oudadane (Linstädter and Kehl 2012) and Ifri Armas (Linstädter 2008), in the Ras Tleta Madari zone, as well as at El Zafrin in the Chafarinas Islands (Gibaja et al. 2012) and Ras Kebdana/Ibouarfatsène (Daugas et al. 2008). Evidence of occupation is also present in the interior of the Eastern Rif, particularly at Hassi Ouenzga cave (Linstädter 2004), as well as several open-air sites along river courses, for example, Mtlili 5 (Linstädter 2008) and Taoungat 1 (Linstädter 2011), both on the Oued (river) Moulouya, Jorf Akhdar on the Oued Isly (Linstädter 2008) and Oued Ben Séguir (Wengler 1985-1986). Still in northeastern Morocco, but further inland, the site of Oued Nachef yielded a mid-fourthmillennium date (Wengler et al. 1994). Only the coastal sites of this period have yielded evidence of domestic species, with cattle, caprines, and pigs all attested in the fourth millennium BC at Ifri Armas (Linstädter 2010). Positive affirmation of crops is thinner, with the presence cereals and pulses in the Eastern Rif dating to the early fourth millennium BC (Linstädter et al. 2016a).
The low presence of domestic crops from Unit $\mathrm{E}$ at Ifri Oudadane (Morales et al. 2013), an intensively investigated site whose earlier phases yielded the first evidence of such in the whole of north Africa (derived from the Iberian peninsula), may indicate that initial farming economies failed on the Mediterranean flank of the Western Maghreb during the period covered in this article. However, further west in Atlantic Morocco, at Kaf el-Baroud cave, domestic cattle, caprines, and pig were still fully exploited at a date now confirmed to fall in the mid-fourth millennium BC (Daugas 2002; Jousse 2017), as dated by radiocarbon and thermoluminescence methods (Fahde 1997; Fregel et al. 2018; Mikdad 1998). The pottery from this site has parallels to that at the coastal cemeteries of Skhirat (Daugas et al. 1989) and El Kiffen (Bailloud and Mieg de Boofzheim 1964; Daugas 2002), both with problematic dates. Kaf el-Baroud is also of key importance for the results of ancient DNA analysis from burials of the mid-fourth millennium BC. These results suggest a strong Iberian component and southward gene flow across the Gibraltar strait, arguably substantially after the initial uptake of farming (Fregel et al. 2018). Last but not least, dates from an excavated hut at Aougni n'ait Ourigh Site C-1300 in the Oukkaïmedden valley confirm the first seasonal occupation of the High Atlas from early in the fourth millennium $\mathrm{BC}$ through to the third, almost certainly by transhumant pastoralists (Rubinos 2014). Interestingly, 


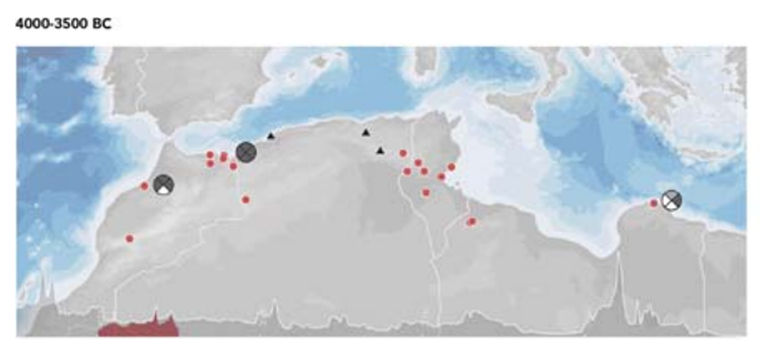

$3500-30008 \mathrm{CC}$

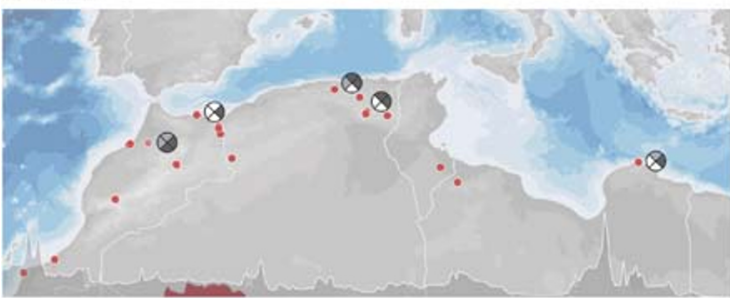

$3000-2500 \mathrm{BC}$

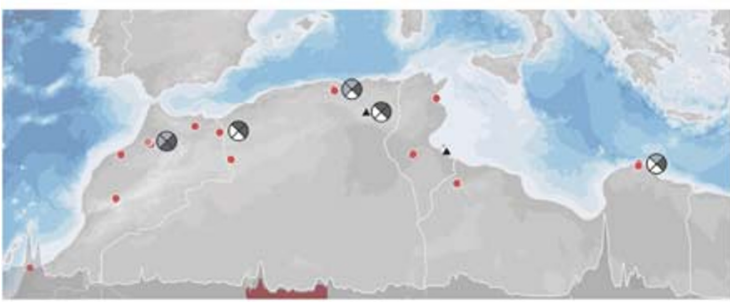

$2500-20008 C$

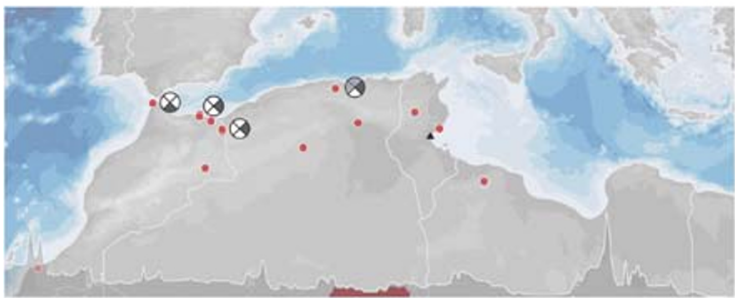

Fig. 2 The overall spatial summary of $14 \mathrm{C}$ dates for each halfmillennium, with associated uptake of domesticates in Mediterranean Africa, and Summed Probability Distribution (SPD) analysis,

pottery at Aougni n'ait Ourigh Site C-1300 shows strong parallels with Saharan comb-impressed techniques of ceramic decoration as well as slighter affinities with the pottery of the Western Maghreb's coastal zone. These suggest initial occupation from a desiccating interior, but also wide connections to the west and north by seasonally mobile people. Taking these insights and the Kaf el-Baroud genetic data together, there is evidence for several major vectors of population flux into the Western Maghreb.

During the second half of the fourth millennium BC, signs of occupation in the Mediterranean zone of the Western Maghreb become more diffuse, though not without new interest. Along the Mediterranean coast,
2000-1500 BC
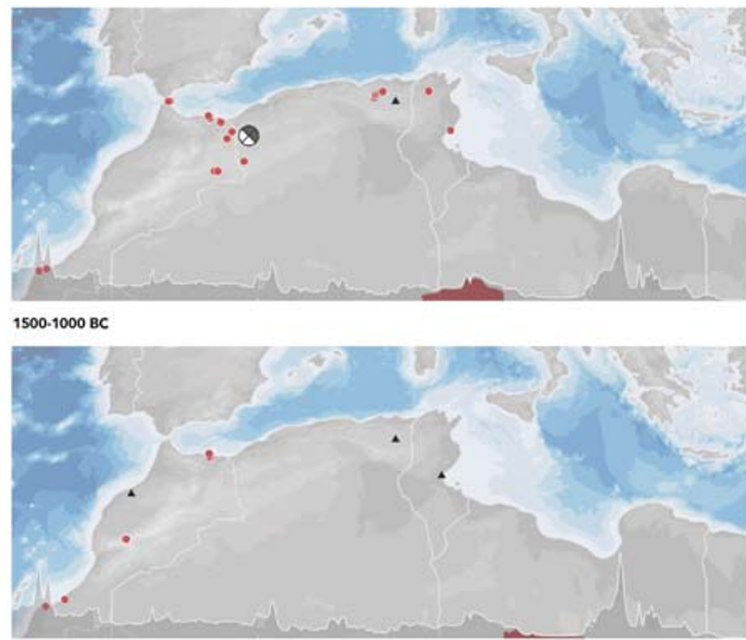

$1000-500 \mathrm{BC}$
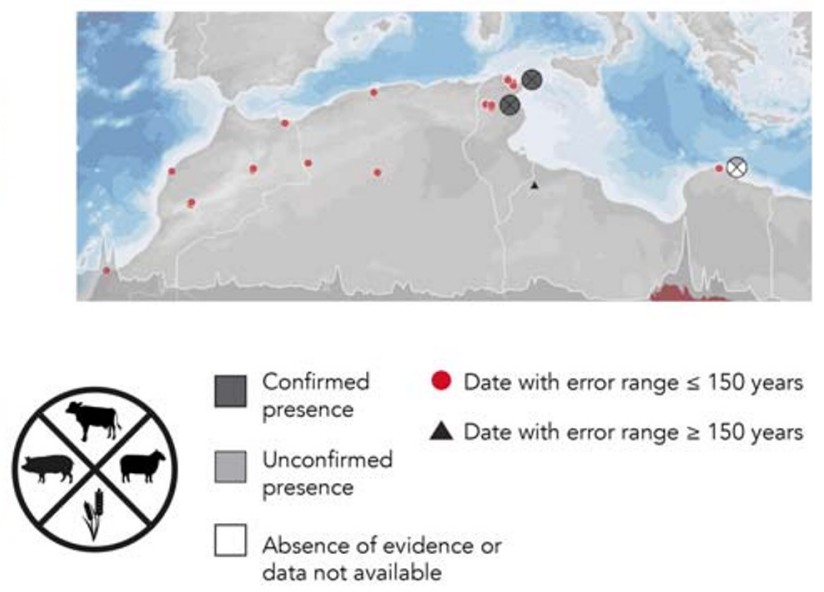

ca. 4000-500 BC (the segmented circles refer to either a single dated site, or several nearby sites of this date, and in all cases are placed as close as possible to the relevant locations)

Ifri Ouzabour has yielded two dates associated with domestic caprines (Nekkal et al. 2015). The Eastern Rif open-air site of Oued Ben Séguir (Wengler 19851986) and the El Heriga cave contribute two and one dates, respectively, with the latter associated with remains of wild ass (Wengler et al. 1994). The increasing prominence of wild ass finds in this, and later phases in the Western Maghreb may be one index of increasing aridity, and perhaps the rolling back of agricultural frontiers in certain areas. Furthermore, it is conceivable that some of the indigenous wild asses of the Maghreb now became drawn into closer relations with expanding mobile pastoral groups in this rugged landscape and may have perhaps been in the process of being 
domesticated into donkeys. Sam (2020) recently emphasizes the surprising lack of genetic and up-to-date faunal analyses of ancestral wild ass and early donkey populations in the Maghreb (the former arguably surviving into Roman times). The author argues for the potential of a local domestication process around this time that could also explain a major clade identified in donkey genetics whose spatial correlate is unsatisfactorily located. Comparison with the more intensively investigated (yet still only ambiguously evidenced in skeletal terms) process of donkey domestication in fifth to fourth millennium $\mathrm{BC}$ northeast Africa suggests that the case for the Maghreb might indeed reward investigation, whether as an instance of independent domestication or, alternatively, acquisition from pools of already domesticated animals further east (Marshall and Weissbrod 2011; Mitchell 2018; Rossel et al. 2008).

Exciting new information from the late fourth millennium $\mathrm{BC}$ is now emerging in Atlantic Morocco, which seems to follow a different trajectory that was based on fully agricultural ways of life in certain areas. The source is the long-known site of Oued Beht, near modern Khémisset, inland between Rabat and the Middle Atlas. This site is now under concerted archaeological investigation for the first time and has yielded radiocarbon dates of ca. 3350-2900 BC (see Table 2). It appears to be a large village that extended over about 20 ha, with fortifications, numerous large rock-cut silos, post-hole footings for houses, and a super-abundant ground-stone assemblage, including hundreds of polished axes, quarrying or mining picks, and large grinding querns - a signature without precedent in the Western Maghreb and persuasively indicative of a substantial and possibly socially complex agricultural society. Equally striking is the quantity and diversity of the Oued Beht pottery, including substantial numbers of painted and polychrome pieces unique to date in northwest Africa and with parallels in southern Spain (Carrasco Rus et al. 2012). The origins of this community, whether indigenous or intrusive and associated with precocious contemporary Iberian developments, remain to be explored. Other later fourth millennium $\mathrm{BC}$ information from Atlantic Morocco remains very patchy. The large and problematically dated coastal cemetery of Skhirat has yielded three dates probably of this age (Daugas et al. 1989), with other dates far further south along the coast in the Tarfaya area, more specifically in Oued el Quar Site G and Megrious Site H (Camps et al. 1973). In the High Atlas, occupation continued at Aougni N'ait Ourigh Site C-1300 (Rubinos 2014; RuizGálvez et al. 2013), and along the upper course of the Moulouya river through the Middle Atlas, where ephemeral "walking horizons" have been identified at the openair site of Blirh (Limondin-Lozouet et al. 2013).

Aside from Oued Beht, the evidence for the first half of the third millennium BC remains diffuse. Taghit Haddouch (Hutterer et al. 2011) and Jorf el Anngra (Wengler et al. 1994) caves attest to activity in the Eastern Rif, the latter again associated with reportedly wild ass, as well as caprines and cattle. Along the Atlantic coast, El Kiffen cemetery, near Casablanca, and the two open-air sites much further south at Létan and Izriten 17 contribute a date apiece (Camps et al. 1973). In the High Atlas, three dates come from Aougni N'ait Ourigh Site C-1300 (Rubinos 2014; Ruiz-Gálvez et al. 2013) and a further one from the deepest stratum of the Elephant's Shelter C-200. These are associated with pottery of Saharan-derived style and provide a useful terminus post quem for the well-known rock art at Elephant's Shelter C-200 (Rubinos 2014). The thermoluminescence dates on pottery from the Amzri painted shelter in the foothills of the central High Atlas near Marrakesh also point to the later third millennium BC (Cle TL 141: $4400 \pm 450$ BP; Cle TL 142: $4000 \pm 500$ BP; Cle TL 143: $4300 \pm 400$ BP) (Ousmoï 1989). Other later third millennium $\mathrm{BC}$ radiocarbon dates concentrate in the Eastern Rif, though most of them document very vestigial and probably pastoral activity. One date for Layers $2 / 3$ in the coastal cave of Ifri Ouzabour is associated with domestic caprines, wild Barbary sheep, and wild cattle (Nekkal et al. 2015). Fireplaces at Bouchih 1 open-air site (Ibouhouten et al. 2010) and sediments from Hajra (Linstädter et al. 2012), both along the Moulouya river, also date to this period. Further west, along the Kert river, two alluvial sections (B and F) have

Table 2 Radiocarbon dates from Oued Beht, Morocco

\begin{tabular}{|c|c|c|c|c|}
\hline Lab number & CRA & Dated material & Feature & Calibrated date (95.4\%) \\
\hline Beta -486878 & $4370 \pm 30 \mathrm{BP}$ & Charcoal & Silo & 3091-2906 BC \\
\hline Beta - 486879 & $4500 \pm 30 \mathrm{BP}$ & Charcoal & Silo & $3352-3096 \mathrm{BC}$ \\
\hline
\end{tabular}


exposed walking horizons characterized by ashy/charcoal layers of possible anthropic origin (El Amrani et al. 2008). To the southwest, Bou Guennouna and Rhirane (Wengler et al. 1994) rockshelters provide two dates with remains of wild ass, and Rhirane also has domestic caprines and undetermined bovids. Outside the Eastern Rif, one radiocarbon date for the second half of the third millennium BC comes from El Khil C cave, near Tangier, associated with rare direct confirmation of ongoing crop cultivation (Martínez Sánchez et al. 2018). Other dates from this period come from beyond the limits of Mediterranean Africa proper, at the Abri de la Dune rockshelter, in the eastern foothills of the High Atlas (Daugas 2006). Beyond the radiocarbon dates, a long-known coastal and hinterland distribution of independently datable later third (and also early second) millennium BC objects of southern Iberian type (primarily ceramic beakers of Atlantic style, and a range of metalwork both in corpore and depicted in rock art) hints at widely networked Western Maghreb communities that have not been understood (Bokbot 2005, 2015, p. 6545) - one beaker sherd, incidentally, comes from Ifri n'Amr o'Moussa cave, immediately adjacent to Oued Beht. Opposite exchanges and movements from the Maghreb to southern Iberia are revealed by African elephant ivory and other objects found at Chalcolithic fortified settlements of the Iberian peninsula (Schuhmacher 2017). An increasingly secure chronological correlation can be established between actual Iberian-type metal objects of third and second millennium BC date found at lowland sites in the Western Maghreb, and depictions of similar types in High Atlas rock art that is now independently dated to the third millennium BC onwards (Chenorkian 1988; Searight 2004). The two regions were presumably linked by seasonally transhumant pastoralism. This emergent long-term practice may explain other much later cultural transfers into the High Atlas, including the first written inscriptions.

The early second millennium BC radiocarbon evidence strikingly excludes most of northwest (Atlantic) Morocco. Benzú cave (Ceuta) yielded two freshly published dates, both falling at the very beginning of the millennium, but not associated with domestic species (Vijande-Vila et al. 2019). Data from the Eastern Rif continues to point to pastoral ways of life. Open-air sites along the Moulouya river (Mtlili 2, Taoungat and Taoungat 5) contribute four dates (Ibouhouten et al. 2010; Linstädter et al. 2012), and Bou Guennouna and
Rirhane two more, both associated with putative wild ass and, in the last case, domestic caprines (Wengler et al. 1994). A date from Grandes Cascades, an open-air site on the Oued el Haÿ river, is associated with both wild and domestic cattle, domestic caprines, and (with the usual caution) wild ass (Wengler and Vernet 1992; Wengler et al. 1994). Five dates from the Eastern Rif come again from the ashy walking horizons of the Kert River deposits (sections A, B, D, G, L) (El Amrani et al. 2008). However, the pattern south of the Gibraltar strait and in Atlantic Morocco may eventually turn out to be quite different. Despite the paucity of radiocarbon dates here (just one, from a burial in the Hafa II cave [Ramos et al. 2011]), an early to mid-second millennium BC date is likely for a series of coffer-grave cemeteries with strong parallels in Argaric Spain, and perhaps for the extraordinary megalithic circle of Mzora (Bokbot 2008). Other early second millennium $\mathrm{BC}$ dates come from far south on the Atlantic coast (Izriten 16, Létan, and Tarfaya Village) (Camps et al. 1973) and in the eastern foothills of the Atlas (Mi Merdaz 2 Est and Oued Ben Ghart) (Daugas 2006). During the second half of the second millennium BC, this broad pattern is maintained, with the Kert river sequence ( $\mathrm{B}$ and $\mathrm{K}$ sections) yielding two dates in the Eastern Rif (El Amrani et al. 2008), and other dates from El Kiffen (Camps et al. 1973), Aougni N'ait Ourigh Site C-700 in the High Atlas (Rubinos 2014), and Izriten Site 16 and Oued el Quar Site G on the Atlantic coast near Tarfaya (Camps et al. 1973; Delibrias et al. 1976). Finally, two thermoluminescence dates on pottery from the Gar Cahal cave near Ceuta fall in the early to mid-second millennium $\mathrm{BC}$, though with large error ranges $(4100 \pm 350 \mathrm{BP}$ [Cler 130a] and $3650 \pm 350$ BP [Cler 130b]; Ousmoï 1989, p. 97). They usefully date the associated style of polished and modeled ceramics, whose chronology is otherwise uncertain. Altogether, the second millennium BC data from the Western Maghreb prove frustratingly fragmented, difficult to interpret, and insufficient as a basis for any substantial social reconstruction of the vital period immediately preceding Iron Age Phoenician connections.

This dearth of information for the pre-Iron Age Western Maghreb continues into the start of the first millennium BC. In terms of radiocarbon dates, numbers remain low but appear to reflect earlier patterns, in the Eastern Rif at El Rhama A (ca. 800 BC) (Linstädter et al. 2012), further south along the upper Moulouya at Blihr (two dates ranging from ca. 1000 and $850 \mathrm{BC}$ ) (Limondin-Lozouet et al. 2013), on the Atlantic coast 
at Ma Izza, south of Casablanca (Close 1988), further south at Tarfaya km 34 (ca. 1050-700 BC) (Camps et al. 1973), and in the High Atlas at Elephant's Frieze C-800 (two dates of ca. 1000-850 and 750-400 BC, probably associated with rock art [Rubinos 2014]). The first date confirms a previous one obtained in 2006 by a Moroccan-Finnish team. A sample of charcoal taken from the bottom of the stratigraphy of a test pit excavated at the foot of the Elephant's Frieze yielded the date $2680 \pm 35$ BP (ca. 900-800 cal. BC) (El Graoui et al. 2008). Secure regional evidence that precedes the appearance of the first Phoenician material at sites such as Lixus and Ceuta is otherwise non-existent, making it very difficult to interpret the strong indigenous component at these and other eighth-seventh century BC sites (see Bokbot 2015, p. 6550-51; Broodbank and Lucarini 2019 p. 243, Papi 2019; Vives-Ferrándiz et al. 2010 for some possibilities).

\section{Central Maghreb}

Radiocarbon-dated sites and associated evidence from the Central Maghreb are much thinner than further west, and more often plagued by wide error margins due to their derivation from fieldwork conducted before the 1980s. An early fourth-millennium date comes from Les Deux Mamelles, located along the coast, east of Oran (Camps et al. 1973). Grotte de la Piste, Brezina, in the southern Atlas piedmont (Jebel Amour), yielded two mid to late fourth-millennium dates (Vernet and Aumassip 1992). Apart from these, fourth millennium $\mathrm{BC}$ dates mainly come from two major cave sequences further east. Four come from the uppermost occupation level (Layer IV) at Capéletti cave, some $190 \mathrm{~km}$ from the coast. Two relate to the mid-fourth millennium, and the other two point to the transition between fourth and third millennia $\mathrm{BC}$, which correspond to the last phase of occupation of the cave. These dates from occupation IV are associated with domestic cattle and caprines, pottery, and polished axes (Roubet 1979). Gueldaman cave in Bejaïa province, ca. $45 \mathrm{~km}$ from the Mediterranean coast, likewise provides one mid to late fourthmillennium $\mathrm{BC}$ date, associated with domestic cattle and caprines and possibly domestic pig. There are five other dates from the third millennium, associated with domestic caprines and unconfirmed domestic cattle and pig. All these dates are also associated with the presence of pottery, and a strong signal of dairying (Chaïd-Saoudi 1987; Jousse 2017; Kherbouche et al. 2014, 2016;
Merzoug et al. 2016). After this, the Gueldaman sequence ends (Kherbouche et al. 2014). The remaining third millennium BC evidence comprises Grotte Piste (three dates) and Biskra (one date) on the southern edge of the Atlas (Vernet and Aumassip 1992). One midthird-millennium date from the open-air site of El Haoutia versant, also located on the southern edge of the Atlas, should be rejected because it is associated with Upper Capsian materials (Camps et al. 1973; Estorges et al. 1969). Another date, ranging from the end of the third to the beginning of the second millennium comes from El Arouya Cave, also located on the immediate northern edge of the Atlas (Vernet and Aumassip 1992). The second millennium BC picture is even more obscure. Only two dates are available: one comes from Mechta el Arbi, west of Constantine (Perrin et al. 2020), and the other from the Ouled Zouai shell midden, also in the area of Constantine (Camps 1968). This paucity continues into the early first millennium $\mathrm{BC}$; only the site of Tipasa 2, in northern Algeria, yielded a date ranging from the tenth to the sixth century BC (Rahmouni et al. 1972). The latest evidence relevant for our analysis dates to the eighth to fourth centuries $\mathrm{BC}$ and comes from the open-air site of Oued Seggueur, Brezina, in the southern Atlas piedmont (Vernet and Aumassip 1992). In short, after the Capéletti and Gueldaman sequences terminate, archaeological evidence concerning even basic ways of life in the Central Maghreb effectively vanishes.

\section{Eastern Maghreb}

In comparison to the richly documented and well-dated Capsian and early post-Capsian "Neolithic" of the Eastern Maghreb (Lubell 2016; Rahmani 2004), the fourth millennium $\mathrm{BC}$ in this region provided 12 dates almost entirely devoid of associated evidence for subsistence and ways of life more generally. The open-air shell middens of Aïn Misteheyia and Wadi Mezeraa, in the Tebessa province of eastern Algeria, have respectively yielded two dates for the early fourth millennium BC and another in the mid-fourth millennium, and none is associated with domesticates (Lubell 1984; Lubell et al. 2009). Interestingly, the two dates from Aïn Misteheyia are related to what is now being recognized as a widespread pattern of intrusive later burials in earlier Capsian middens (Lubell et al. 2009). A high margin of error date, spanning from the second half of the fourth to the first half of the third millennium $\mathrm{BC}$, comes from $\mathrm{Bou}$ 
Zabaouine Cave 2, in the Constantine region (Camps et al. 1973). From Tunisia come another eight dates: one from Jaatcha rockshelter, not far from the Algerian border (Camps 1968); another three from the coastal sites of Oued el Akarit, Henchir Jel 3 and Zarzis - the last one with a high error range, which makes it span from mid-fourth to mid-third millennia BC (Brosche et al. 1976; Fontes et al. 1983; Oueslati 1995); two dates come from Djerid in central Tunisia, near Gafsa (Brosche et al. 1976); one, obtained on human remains, comes from a tumulus of El Menaguib cemetery, southeast of Tataouine (Miniaoui 2013); the last two dates come from the Chott el Cherid area (open-air sites 15/6 and 15/8) in southern Tunisia (di Lernia et al. 2017). The situation in the third millennium BC is poorer, with three coastal dates (one date apiece) from Sebkhet Halek el-Menjel-1 (Hergla) (Saliège et al. 2013), well after the end of a long sequence starting in the later seventh millennium BC, Oued el Akarit and Gtoaa Ejali 3 (Ben Moussa 2008; Rognon 1987). Another two dates come from the Chott el Jerid area (open-air sites 15/12 and 15/18) (di Lernia et al. 2017). The very last thirdmillennium date comes from the natural section of Wadi Sbeïtla Wadi el Hammar (HAM) (Zerai 2009).

The second millennium $\mathrm{BC}$ data are even more inadequate but again include further hints of new kinds of funerary practices. Two burials dating to the early second millennium BC (ca. 1850-1550 BC) are simple but (unlike earlier traditions) extended burials in the pre-Roman layers of the Maison du Trifolium at Dougga, northern Tunisia. Another extended burial was inserted into the earlier shellmidden of Aïoun Berriche - Canrobert 12 (Jackes et al. 2015; Khanoussi et al. 2004; Lubell et al. 2009). The spread of megalithic funerary dolmens across the Eastern Maghreb remains poorly dated, but is suggested to have started ca. 1500-1400 BC (Belmonte et al. 2003. p. 307; Khanoussi et al. 2004, p. 51), if not earlier (Kuper and Gabriel 1979p. 41). There are parallels with contemporary monuments in Malta and Apulia (Iacono 2018, p. 71-72; Recchia 2011). Single dates apiece from Oued el Akarit and Gtoaa Ejali 3 attest to coastal occupation in the millennium before Carthage (Ben Moussa 2008; Petit-Maire et al. n.d.).

Of the 45 radiocarbon dates for the whole Mediterranean Africa beyond Egypt that fall in the early first millennium BC, twenty-two come from Phoenician Carthage, starting in the later ninth century BC (Docter et al. 2004; Nijboer and van der Plicht 2008; van der Plicht et al. 2009). Three establish a slightly earlier, tenth-ninth century BC, start for Phoenician activity in Utica (López Castro et al. 2016). But, five crucial dates, spanning from ca. 1000 to $600 \mathrm{BC}$, provide a firm chronology for the key indigenous site of Althiburos, located inland on Mt. Ouartane. This site provides the first definite data for a full farming economy and husbandry practices, west of the Nile Delta and east of Morocco. It shows that domestic stock (cattle, caprines, and pigs), as well as domesticated cereals and pulses, were already in place just before the Carthage sequence began (Sanmartí et al. 2012). When considered along with the second millennium BC trans-Mediterranean parallels for the dolmens of the Eastern Maghreb, the discovery at Althiburos raises the possibility of a late, second millennium BC farming expansion southward across the Sicilian strait. The last three dates for the early first millennium BC come from the Tunisian sites of Henchir Mided and Sidi Jdidi, which yielded two and one, respectively.

\section{Tripolitania}

In the Jefara plain of northwestern Libya, several open-air sites demonstrate occupation between the fourth and first millennia BC (Barich 2014; Lucarini 2009, 2013). Site SJ$03-83$ is situated near three springs. It is characterized by a large number of steinplatz-type surface hearths and rich lithic assemblages, four of which have been radiocarbon dated and interpreted as temporary campsites for nomadic pastoral groups moving along the Jebel Gharbi hills. Two of these dates precede the period covered in this paper by one to two millennia, but the date from one hearth affirms activity during the first half of the fourth millennium BC, while another hearth was dated between ca. 1200 and 550 BC. Sediments from the open-air Sites SJ-06-87 and SJ06-88 were dated to the fourth and first half of the third millennia BC (Barich 2014). Lithic artifacts from these sites include bifacial arrowheads, which confirm the enduring importance of hunting in the area. A final date between the end of the third and the start of the second millennium $\mathrm{BC}$ comes from an open-air site along the Wadi Ghan, south of Garian, on the eastern edge of Jebel Gharbi (Barich pers. comm. 2017). Between them, these dates attest to some level of activity in the Jefara/Jebel Gharbi area across most of our timespan, though patchily and with a complete dearth of evidence further east within the overall region of the Gulf of Syrte hinterland. The archaeological signature is consonant with nomadic or transhumant pastoral practices, supplemented by hunting. 
Cyrenaica

In Cyrenaica, intriguing and regionally solitary evidence comes from McBurney's excavation of the upper strata at Haua Fteah, immediately below Greek and Roman finds (McBurney 1967, p. 328). The recently renewed excavations by the Cyrenaica Prehistory Project (CPP) have mainly targeted the earlier strata within the previously opened area and left such later deposits largely untouched. These seldom-discussed later strata, roughly corresponding to the uppermost meter of the cave sequence, have produced five radiocarbon dates. Four come from what McBurney termed the Late Neolithic and Early Historic occupation (respectively the end of his Layer VI, and Layer V). Two of these, one coming from McBurney's excavation and the other from the CPP Project's Context 129 (Hill 2015; McBurney 1967, p. 71 table III.1) belong to the fourth millennium BC. The third date (CPP's Context 128) spans the fourth-third millennium transition, and the last (CPP's Context 130) falls in the early third millennium BC. It is unclear whether the absence of the later third and second millennia BC dates reflects a lack of sampling or temporary cessation of occupation. The most recent date comes from CPP's Context 126, corresponding to McBurney's Layer IV (Early Historic), ranges from ca. 900 to $810 \mathrm{BC}$ and confirms that the cave was still (or again) used at the start of the first millennium $\mathrm{BC}$, a few centuries before the first appearance of Greek pottery. The presence of domestic cattle associated with these five dates from Haua Fteah is not confirmed, but there are indications of domestic caprines and undetermined equids (Stimpson pers. comm. 2019). Consistent with all the late seventh to fifth millennia $\mathrm{BC}$ dates from the site (i.e., the so-called Neolithic), domestic crops remain absent, even if it cannot be excluded that this absence of evidence relies on the very limited number of analyzed samples (Morales pers. comm. 2020). Textual sources relating to the history of early Greek colonization of Cyrenaica in the seventh to sixth centuries BC provide our first definite evidence for farming regimes in the region.

A preliminary restudy of the approximately 150 coarse sherds retained from these strata confirms marked technological differences from the finer, wellburnished sherds of the preceding "Early Neolithic" levels. Moreover, three macroscopically distinct fabrics (dominated by calcite inclusions and shell temperpresumably local, but the two others arguably not), suggest that pottery was reaching the cave from regions of varied bedrock, and therefore potentially over some distance. Fuller study of this stratified material might refine the dating of the otherwise very broadly attributed sherd and lithic scatters, and small tumuli, that comprise the remainder of the data, associated with pastoral activity, for this period in Cyrenaica and the Marmarica coast to its east (Hulin 2001; Hulin et al. 2009, 2010)note in particular one indigenous assemblage of late second millennium BC date, as determined by its stratification above the Egyptian occupation layer at the Ramessid fort of Zawiyet Umm el-Rakham, east of Marsa Matruh (Simpson 2000).

\section{Discussion and Conclusion}

The foregoing shows that most of Mediterranean Africa witnessed some form of occupation during the three thousand years that concern us here. It is not clear whether the enduring gaps in the evidence relate to the nature of archaeological research emphasis or the serendipities of exploration. Clearly, the precise ways of life that sustained people in each region during this period have been under-explored. Domesticated animals, mainly caprines and cattle (all already present during the sixth-fifth millennia BC), remained widely attested throughout the region. Yet, between the sixth and fifth millennium $\mathrm{BC}$ in the Western Maghreb, and Althiburos, several thousand years later at the other end of the Maghreb, there is only minimal evidence of domestic crops or a full mixed farming economy. The strongest candidate for a continuous farming trajectory is undoubtedly the Western Maghreb, especially its Atlantic coast and hinterland, a region with earlier signs of agriculture, and later the notable investment in silos and grinding stones at the large settlement site of Oued Beht. This region was also in contact with Iberian groups during the third and second millennia BC. At the other extreme, it remains entirely plausible that farming only reached Cyrenaica after the end of our period via overseas Aegean colonists, unless elements filtered in slightly earlier from the Nile via Marmarica (for example, at late second-millennium BC Zawiyet Umm el-Rakham there are textual hints of local people working fields for the Egyptian garrison), as has been argued for the Fezzan region of the Sahara around the start of the first millennium BC (Pelling 2005; van der Veen 2006, 2010). In between these regions, there is a 
dearth of positive proof that crops expanded from the Western Maghreb to become established across the Central and Eastern Maghreb, and therefore a real possibility that these areas remained, for much of our period, pastoral rather than agricultural. If so, this raises the question as to what the mixed farming at Althiburos, which narrowly but decisively pre-dates the foundation of Carthage, actually represents. Is it the late phase of an otherwise invisible pan-Maghrebian farming, that extended unbroken from the mid-sixth to early first millennium $\mathrm{BC}$ ? Or is it a relatively young and intrusive phenomenon that was associated with the widespread dolmen distribution in this same region, and therefore derived from an influx of farming groups from the northern side of the Sicilian strait during the second millennium BC - in other words, a separate overseas introduction preceding the better known Phoenician-Greek horizon? If so, what was the chronology of its internal and westward spread across the Maghreb, before and after the foundation of the initially seaward-oriented Carthage?

And if the sixth- to fifth-millennium BC farmers failed in the long-term to spread throughout Mediterranean Africa, why was this the case? In the east, the answer is likely to lie among the specific adaptations made in the aquatic conditions of the Nile corridor, and their non-transferability to the drier landscapes to the immediate west. However, such arguments are less convincing for the Maghreb, given its broad environmental similarity to much of the remaining Mediterranean, from which its first crops arrived, and the fact that (unlike the Sahara, and also parts of the littoral zone in eastern Mediterranean Africa, Cyrenaica excepted) later Holocene aridification was not extreme enough to push it beyond the potential scope of agriculture. The presence and absence of significant river catchments could be one significant factor (Fig. 3). Their absence between the Nile and the border of the Eastern Maghreb contrasts markedly with the Western Maghreb, where copious rivers drain from the High and Middle Atlas, as well as the Eastern Rif, potentially favoring the development of farming enclaves in coastal plains or gentle hill landscapes, such as the Tingitana peninsula, the Eastern Rif foothills, or (as in the case of Oued Beht) the piedmont of the Middle Atlas. It is interesting to note that in the Central Maghreb, the catchment area of Oued Chelif, the longest river in Algeria, which rises in the Saharan Atlas, runs through the Tell Atlas and flows into the Mediterranean north of Mostaganem, has not been systematically surveyed in recent times. If there is evidence of farming settlements to be discovered in the Central Maghreb, this might be a good place to look. A comparable phenomenon may be discernible in the concentration of dolmens along the course of the Medjerda (ancient Bagradas) river in Eastern Maghreb (Broodbank and Lucarini 2019, p. 234, Fig. 10). Another possibility is that, in demographic terms, the initial farming populations were small, and agriculture, therefore, simply failed to take off. But this did not deter the modest groups of early farmers who settled the outlying islands and peninsulas all over the Mediterranean from developing successful agricultural regimes. A more likely reason for the delayed agricultural takeoff in most of Mediterranean Africa is the robust and resilient nature of local hunter-gatherer and pastoral groups. It appears that by the time exogenous crops became locally available, Mediterranean Africa had for so long been in the orbit of

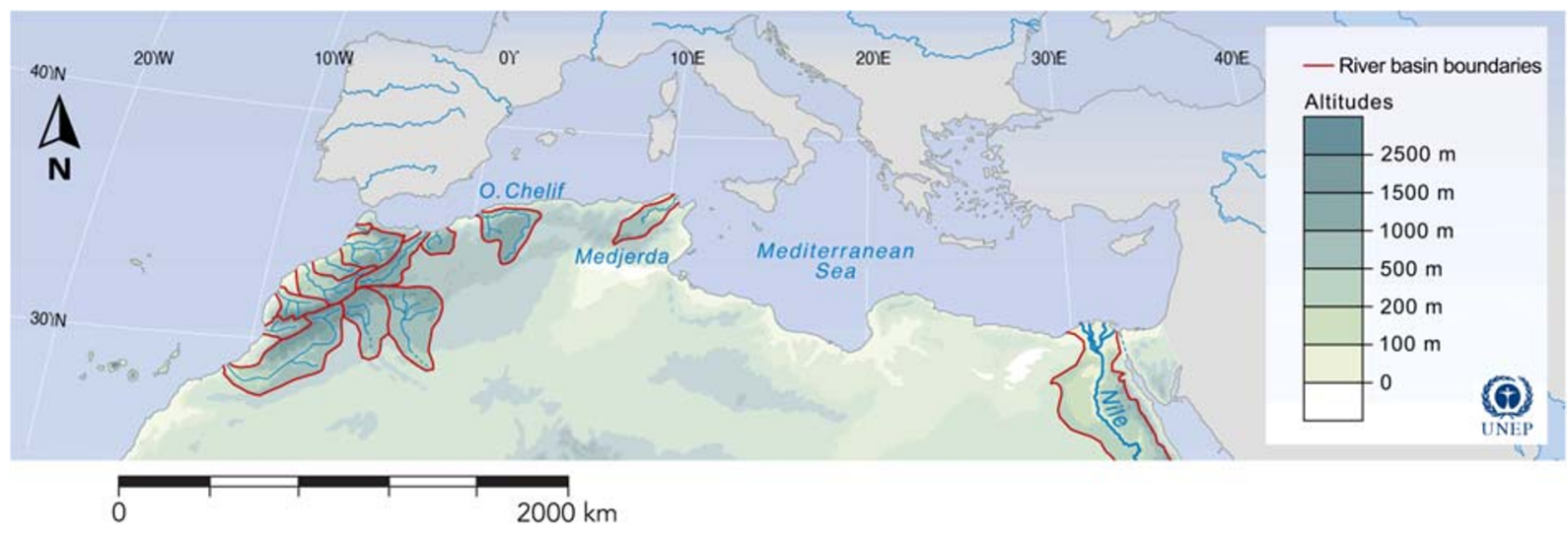

Fig. 3 The major river basins of Mediterranean Africa (modified after the original by P. Rekacewicz, visionscarto.net, elaborated from Rekacewicz 1996, Revenga et al. 1998, and Wolf et al. 1999) 
the Saharan foraging and pastoral world that most of its inhabitants effectively rejected agricultural lifestyles. Conversely, by the time the grand tradition of Saharan societies was destroyed by desertification, this choice may have become in effect locked in until new, intrusive farmers reappeared several millennia later.

In much the same vein as the pastoralist orientation, the enduring tradition of wild plant exploitation may also lie behind the widespread indifference of local communities to farming practices. Wild plants were one of the most important sources of food for people along both the Saharan belt (Dunne et al. 2016; Fahmy 2014; Lucarini 2014; Lucarini and Radini 2020; Mercuri et al. 2018; Wasylikowa 2001), and the Mediterranean coast (Lucarini et al. 2016), not only in the Epipalaeolithic times but also during the Neolithic. In particular, wild plants such as acorns and pine nuts have been recorded at several sites in Mediterranean Africa (Barker et al. 2008; p. $208-213$; 2009, p. $83-88$; 2010, p. 76-78; Morales 2018; Morales et al. 2015), and are still widely consumed in the Maghreb, providing a rich source of calories. The Ait Abdi tribe, located in the Moroccan High Atlas, exemplifies this tradition. Until roughly 50 years ago, the members of this highly nomadic tribe practiced a diversified use of resources based on the intensive exploitation of acorns and juniper fruit, herding of domestic sheep and goat, hunting wild Barbary sheep, consuming locusts, and small-scale cultivation of cereals (Morales pers. comm. 2020). During their movements, cereals, butter, locusts, and often valuables were stored in collective granaries built into the cliffsides, such as those at Aoujgal (Boutferda) overlooking the Oued Attach.

Turning to the second point on our agenda, there is currently nothing to contradict the Herodotean distinction between pastoralists in the east and farmers in at least parts of the west, around the time of Phoenician and Greek colonization. Greatly improved archaeological data will be necessary before indigenous-colonial interrelations during the first few centuries of the first millennium BC can be fully explored in all their varieties. The Althiburos settlement, new early levels at Utica, and the finds in upper-level Haua Fteah indicate the possibilities of what may lie ahead, and a substantial infilling of our knowledge of the preceding second and early first millennia BC in the Western Maghreb will be absolutely vital.

Acknowledgments We warmly thank Enrico Crema, Augusto Palombini, and Toby Wilkinson for their invaluable help with the preparation of the MedAfriCarbon database and web application, and again Toby Wilkinson for the support in elaborating Fig. 2. Our gratitude also goes to Barbara E. Barich, Jacob Morales, and Christopher Stimpson for the personal communications they provided, to Philippe Rekacewicz for providing the high resolution file of Fig. 3, and to Mohamed Abioui for providing the copies of some of the publications cited in this paper. This paper is dedicated to the loving memory of Lahcen o'Hmad Bokbot.

Author Contributions Giulio Lucarini and Cyprian Broodbank contributed to the study conception and design. Material preparation, data collection and analysis were performed by Giulio Lucarini. Youssef Bokbot contributed the section about Oued Beht site and thermoluminescence dating performed at Moroccan sites. The first draft of the manuscript was written by Giulio Lucarini and Cyprian Broodbank and all authors commented on previous versions of the manuscript. All authors read and approved the final manuscript.

Funding We are greatly indebted to the Leverhulme Trust for providing the major funding for our MedAfrica research project (RPG-2016-261). Further financial support came from the McDonald Institute for Archaeological Research, Italian Ministry of Foreign Affairs and International Cooperation, and the IPOCAN, MIUR project via the International Association for Mediterranean and Oriental Studies (ISMEO). ISMEO financially covered the publication costs of this open-access paper.

\section{Compliance with Ethical Standards}

Conflict of Interest The authors declare that they have no conflict of interest.

Open Access This article is licensed under a Creative Commons Attribution 4.0 International License, which permits use, sharing, adaptation, distribution and reproduction in any medium or format, as long as you give appropriate credit to the original author(s) and the source, provide a link to the Creative Commons licence, and indicate if changes were made. The images or other third party material in this article are included in the article's Creative Commons licence, unless indicated otherwise in a credit line to the material. If material is not included in the article's Creative Commons licence and your intended use is not permitted by statutory regulation or exceeds the permitted use, you will need to obtain permission directly from the copyright holder. To view a copy of this licence, visit http://creativecommons.org/licenses/by/4.0/.

\section{References}

Bailloud, G., \& Mieg de Boofzheim, P. (1964). La Nécropole néolithique d'El Kiffen, près de Tamaris (Province de Casablanca, Maroc). Libyca, 12, 95-171.

Ballouche, A., \& Marinval, P. (2003). Données palynologiques et carpologiques sur la domestication des plantes et l'agriculture 
dans le Néolithique ancien du Maroc septentrional (site de Kaf Taht el-Ghar). Revue d'Archéométrie, 27, 49-54.

Barich, B. E. (2014). Northwest Libya from the early to late Holocene: New data on environment and subsistence from the Jebel Gharbi. Quaternary International, 320, 15-27.

Barich, B. E., Lucarini, G., Hamdan, M. A., \& Hassan, F. A. (Eds.). (2014). From lake to sand. The archaeology of Farafra oasis, western desert, Egypt. Florence: All'Insegna del Giglio.

Barker, G., Basell, L., Brooks, I., Burn, L., Cartwright, C., Cole, F., et al. (2008). The Cyrenaican Prehistory Project 2008: The second season of investigations of the Haua Fteah cave and its landscape, and further results from the initial (2007) fieldwork. Libyan Studies, 39, 175-221.

Barker, G., Antoniadou, A., Barton, H., Brooks, I., Candy, I., Drake, N., et al. (2009). The Cyrenaican Prehistory Project 2009: The third season of investigations of the Haua Fteah cave and its landscape, and further results from the 20072008 fieldwork. Libyan Studies, 40, 55-94.

Barker, G., Antoniadou, A., Armitage, S., Brooks, I., Candy, I., Connell, K., et al. (2010). The Cyrenaican Prehistory Project 2010: The fourth season of investigations of the Haua Fteah cave and its landscape, and further results from the 20072009 fieldwork. Libyan Studies, 41, 63-88.

Barker, G., Bennett, P., Farr, L., Hill, E., Hunt, C., Lucarini, G., et al. (2012). The Cyrenaican Prehistory Project 2012: The fifth season of investigations of the Haua Fteah Cave. Libyan Studies, 43, 115-136.

Belmonte, J. A., Perera Betancort, M. A., Marrero, R., \& Tejera Gaspar, A. (2003). The Dolmens and Hawanat of Africa Proconsularis revisited. Journal for the History of Astronomy, 34, 305-320.

Ben Moussa, S. (2008). A propos des datations radiométriques récentes de la Rammadiya de Sebkhet Halek el Menjel. AFRICA-Revue des Etudes Phéniciennes-Puniques et des Antiquités Libyques, 14, 47-62.

Bokbot, Y. (2005). La Civilizacion del Vaso Campaniforme en Marruecos y la cuestion del sustrato Calcolitico Precampaniforme. In M. Rojo Guerra, R. Garrido-Peña, \& I. García-Martínez de Lagrán (Eds.), El Campaniforme en la Peninsula Ibérica y su Contexto Europeo (pp. 137-159). Valladolid: Universidad de Valladolid.

Bokbot, Y. (2015). Protohistoire du Maroc. Encyclopédie Berbère, $39,6543-6561$.

Broodbank, C. (2013). The making of the Middle Sea: A history of the Mediterranean from the beginning to the emergence of the Classical World. London: Thames and Hudson.

Broodbank, C., \& Lucarini, G. (2019). The dynamics of Mediterranean Africa, ca. 9600-1000 BC: An interpretative synthesis of knowns and unknowns. Journal of Mediterranean Archaeology, 32(2), 195-268.

Brosche, K.-U., Molle, H.-G., \& Schulz, G. (1976). Geomorphologische untersuchungen imöstlichen Kroumirbergland (Nordtunesien, Gebietöstlich von Tabarka). Eiszeitalter und Gegenwart, 27, 143-158.

Camps, G. (1968). Tableau chronologique de la préhistoire récente $\mathrm{du}$ Nord de 1'Afrique: Première synthèse des datations absolues obtenues par le carbone 14. Bulletin de la Société préhistorique française. Études et travaux, 65(2), 609-622.
Camps, G., Delibrias, G., \& Thommeret, J. (1973). Chronologie des civilisations préhistoriques du nord de l'Afrique d'après le radiocarbone. Libyca, 21, 65-90.

Carrasco Rus, J. L., Pachón Romero, J. A., \& Gámiz Jiménez, J. (2012). Las cerámicas neolíticas pintadas en Andalucía y sus contextos arqueológicos. Antiquitas, 24, 17-79.

Chaïd-Saoudi, Y. (1987). Les mammifères holocènes des gisements préhistoriques de Gueldaman-Akbou (Bédjaia), Columnata (Tiaret) et Ti-n Hanakaten (Djanet) en Algérie. $\mathrm{Ph} . \mathrm{D}$. thesis. Université de Lyon 1, Lyon.

Cheddadi, R., Lamb, H., \& Guiot, J. (1998). Holocene climatic change in Morocco: A quantitative reconstruction from pollen data. Climate Dynamics, 14(12), 883-890.

Chenorkian, R. (1988). Les armes métalliques dans l'art protohistorique de l'Occident Méditerranéen. Paris: Éditions du CNRS.

Close, A. E. (1988). Current research and recent radiocarbon dates from Northern Africa, III. The Journal of African History, 29(2), 14-176.

Daugas, J. (2002). Le Néolithique du Maroc: Pour un modèle d'évolution chronologique et culturelle. Bulletin d'Archéologie Marocaine, 19, 135-175.

Daugas, J. (2006). Programme GENÉMAR - Rapport sur la campagne 2006 et prospective 2007. In J.-P. Raynal (Ed.), Mission Littoral Maroc. Rapport 2006, Projects 2007 (pp. 16-23).

Daugas, J., Raynal, J., Ballouche, A., Occhietti, S., Pichet, P., \& Evin, et al. (1989). Le Néolithique nord-atlantique du Maroc: premier essai de chronologie par le radiocarbone. Comptes rendus de l'Académie des sciences. Série II, Mécanique, physique, chimie, sciences de l'univers, sciences de la terre, 308, 681-687.

Daugas, J., El Idrissi, A., Ballouche, A., Marinval, P., \& Ouchaou, B. (2008). Le Néolithique ancien au Maroc septentrional: données documentaires, sériation typochronologique et hypothèses génétiques. Bulletin de la Société préhistorique française, 105(4), 787-812.

Delibrias, G., Ortlieb, L., \& Petit-Maire, N. (1976). New 14C data for the Atlantic Sahara (Holocene): Tentative interpretations. Journal of Human Evolution, 5(6), 535-546.

di Lernia, S., Anagnostou, P., Ben Fraj, T., Ben Nasr, J., Boukhchim, N., Boussoffara, R., et al. (2017). First archaeological investigations in the Chott el Jerid area, Southern Tunisia. Scienze dell'Antichità. Storia, Archeologia, Antropologia, 23(1), 3-19.

Docter, R. F., Niemeyer, H. G., Nijboer, A. J., \& van der Plicht, J. (2004). Radiocarbon dates of animal bones in the earliest levels of Carthage. In G. Bartoloni, \& F. Delpino (Eds.), Oriente e Occidente: Metodi e Discipline a Confronto. Riflessioni sulla cronologia dell'eta dell Ferro in Italia. Mediterranea: Quaderni Annuali dell'Istituto di Studi sulle Civiltà Italiche e del Mediterraneo Antico del Consiglio Nazionale delle Ricerche, 1, (pp. 557-577). Pisa/Roma: Istituti Editoriali e Poligrafici Internazionali.

Drake, N. A., Blench, R. M., Armitage, S. J., Bristow, C. S., \& White, K. H. (2011). Ancient watercourses and biogeography of the Sahara explain the peopling of the desert. PNAS, 108(2), 458-462.

Dunne, J., Evershed, R. P., Salque, M., Cramp, L., Bruni, S., Ryan, K., et al. (2012). First dairying in green Saharan Africa in the fifth millennium BC. Nature, 486, 390-394. 
Dunne, J., Mercuri, A. M., Evershed, R., Bruni, S., \& di Lernia, S. (2016). Earliest direct evidence of plant processing in prehistoric Saharan pottery. Nature Plants, 3, 16194.

El Amrani, M., Macaire, J., Zarki, H., Bréhéret, J., \& Fontugne, M. (2008). Contrasted morphosedimentary activity of the lower Kert River. Comptes Rendus Geoscience, 340, 533-542.

El Graoui, M., Alifriqui, M., Jungner, H., Nahid, A., \& SearightMartinet, S. (2008). Recherche d'indices chronologiques sur le passage des graveurs de rochers de l'Oukaïmeden (Haut Altas, Maroc). Sahara, 19, 105-108.

Estorges, P., Aumassip, G., \& Dagorne, A. (1969). El Haouita, un exemple de remblaiement Fini-Wurmien. Libyca, XVII, 53-91.

Fahde, K. (1997). Nouvelle méthode de datation par thermoluminescence des échantillons archéologiques. Ph.D. thesis. Université de Caddi Ayyad, Marrakech.

Fahmy, A. G. (2014). Plant food resources at Hidden Valley. In B. E. Barich, G. Lucarini, M. A. Hamdan, \& F. A. Hassan (Eds.), From lake to sand. The archaeology of Farafra oasis, western desert, Egypt (pp. 333-344). Florence: All'Insegna del Giglio.

Fontes, J. C., Coque, R., Dever, L., Filly, A., \& Mamou, A. (1983). Paléohydrologie isotopique de l'Oued el Akarit (Sud Tunisien) au Pléistocene supérieur et à l'Holocène. Palaeogeography, Palaeoclimatology, Palaeoecology, 43, 41-62.

Fregel, F., Méndez, F. L., Bokbot, Y., Martín-Socas, D., Camalich-Massieu, M. D., Santana, J., et al. (2018). Ancient genomes from North Africa evidence prehistoric migrations to the Maghreb from both the Levant and Europe. PNAS, 115(26), 6774-6779.

Garcea, E. A. A. (2006). Semi-permanent foragers in semi-arid environments of North Africa. World Archaeology, 38, 197-219.

Gautier, A. (2014). Animal remains from the Hidden Valley Neolithic site, Farafra oasis. In B. E. Barich, G. Lucarini, M. A. Hamdan, \& F. A. Hassan (Eds.), From lake to sand. The archaeology of Farafra oasis, western desert, Egypt (pp. 369-374). Florence: all'Insegna del Giglio.

Gibaja, J. F., Carvalho, A. F., Rojo, M., Garrido, R., \& García, I. (2012). Production and subsistence strategies at El Zafrín (Chafarinas Islands, Spain): New data for the early Neolithic of North-West Africa. Journal of Archaeological Science, 39(10), 3095-3104.

Giraudi, C., Mercuri, A. M., \& Esu, D. (2013). Holocene palaeoclimate in the northern Sahara margin (Jefara Plain, northwestern Libya). The Holocene, 23, 339-352.

Hawass, Z., Hassan, F. A., \& Gautier, A. (1988). Chronology, sediments, and subsistence at Merimda Beni Salama. The Journal of Egyptian Archaeology, 74, 31-38.

Hill, E. (2015). The radiocarbon dating of terrestrial molluscs in North East Libya. Ph.D. thesis. Queens University, Belfast.

Holdaway, S. J., \& Wendrich, W. (Eds.). (2017). Desert Fayum reinvestigated: The early to mid-Holocene landscape archaeology of the Fayum North Shore, Egypt. Los Angeles: UCLA, Cotsen Institute of Archaeology Press.

Hublin, J.-J., Ben-Ncer, A., Bailey, S. E., Freidline, S. E., Neubauer, S., Skinner, M. M., et al. (2017). New fossils from Jebel Irhoud, Morocco and the pan-African origin of Homo sapiens. Nature, 546, 289-292.

Hulin, L. (2001). Marmaric wares: New Kingdom and later examples. Libyan Studies, 32, 67-78.
Hulin, L., Timby, J., \& Mutri, G. (2009). The Western Marmarica coastal survey 2009: Preliminary report. Libyan Studies, 40, 179-187.

Hulin, L., Timby, J., Muftah, A. M., \& Mutri, G. (2010). Western Marmarica coastal survey 2010: Preliminary report. Libyan Studies, 41, 155-162.

Hunt, C. O., Reynolds, T. G., El-Rishi, H. A., Buzaian, A., Hill, E., \& Barker, G. W. (2011). Resource pressure and environmental change on the North African littoral: Epipalaeolithic to Roman gastropods from Cyrenaica, Libya. Quaternary International, 244, 15-26.

Hutterer, R., Mikdad, A., \& Ripken, T. E. J. (2011). Species composition and human exploitation of terrestrial gastropods from Taghit Haddouch, an Early Holocene archaeological site in NE Morocco. Archiv für Molluskenkunde: International Journal of Malacology, 140(1), 57-75.

Iacono, F. (2018). The archaeology of Late Bronze Age interaction and mobility at the gates of Europe: People, things, and networks around the southern Adriatic Sea. London: Bloomsbury Academic Press.

Ibouhouten, H., Zielhofer, C., Mahjoubi, R., Kamel, S., Linstädter, J., Mikdad, A., et al. (2010). Archives alluviales holocènes et occupation humaine en Basse Moulouya (Maroc nord-oriental). Géomorphologie: relief, processus, environnement, 1, 41-56.

Jackes, M., Lubell, D., \& Crann, C. (2015). Dating and redating Capsian skeletons 3A-4 and 3A-7, Aïn Berriche (Algeria). Journal of Archaeological Science: Reports, 4, 78-85.

Jaouadi, S., Lebreton, V., Bout Roumazeilles, G., Siani, R., Lakhdar, R., Boussoffara, L., et al. (2016). Environmental changes, climate and anthropogenic impact in south-east Tunisia during the last 8 kyr. Climate of the Past, 12, $1339-1359$.

Jousse, H. (2017). Atlas of mammal distribution through Africa from the $L G M(18 \mathrm{ka})$ to modern times: The zooarchaeological record. Oxford: Archaeopress.

Khanoussi, M., Ritter, S., \& von Rummel, P. (2004). The GermanTunisian project at Dougga: First results of the excavations south of the Maison du Trifolium. Antiquités Africaines, 40-41, 43-66.

Kherbouche, F., Hachi, S., Abdessadok, S., Sehil, N., Merzoug, S., Sari, L., et al. (2014). Preliminary results from excavations at Gueldaman Cave GLD1 (Akbou, Algeria). Quaternary International, 320, 109-124.

Kherbouche, F., Dunne, J., Merzoug, S., Hachi, S., \& Evershed, R. P. (2016). Middle Holocene hunting and herding at Gueldaman Cave, Algeria: An integrated study of the vertebrate fauna and pottery lipid residues. Quaternary International, 410, 50-60.

Knapp, A. B., \& van Dommelen, P. (Eds.). (2014). The Cambridge prehistory of the Bronze and Iron Age Mediterranean. New York: Cambridge University Press.

Kuper, R., \& Gabriel, B. (1979). Zur Urgeschich-te des Maghreb. In H. G. Horn \& C. B. Rüger (Eds.), Die Numider. Reiter und Könige nördlich der Sahara (pp. 23-42). Bonn.

Kuper, R., \& Kröpelin, S. (2006). Climate-controlled Holocene occupation in the Sahara: motor of Africa's evolution. Science, 313, 803-807.

Limondin-Lozouet, N., Haddoumi, H., Lefèvre, D., Ghamizi, M., Aouraghe, H., \& Salel, T. (2013). Holocene molluscan succession from NE Morocco: Palaeoenvironmental reconstruction and biogeographical implications. Quaternary International, 302, 61-76. 
Linseele, V., Van Neer, W., Thys, S., Phillipps, R., Cappers, R., Wendrich, W., et al. (2014). New archaeozoological data from the Fayum 'Neolithic' with a critical assessment of the evidence for early stock keeping in Egypt. PLOS ONE, 9, e108517. https://doi.org/10.1371/journal.pone.0108517.

Linstädter, J. (2004). Zum Frühneolithikum des westlichen Mittelmeerraumes - die keramik der Fundstelle Hassi Ouenzga. Series 9. Bonn: AVA-Forschungen Band.

Linstädter, J. (2008). The Epipalaeolithic-Neolithic-Transition in the Mediterranean region of Northwest Africa. Quartär, 55, $41-62$.

Linstädter, J. (2010). Recherches récentes sur les sites en grotte du Néolithique ancien de l'Est marocain. Mémoire de la Société préhistorique française, 51, 227-235.

Linstädter, J. (2011). The Epipalaeolithic-Neolithic transition in the Eastern Rif Mountains and the Lower Moulouya valley, Morocco. In J. F. Gibaja, A. F. Carvalho, \& N. F. Bicho (Eds.), The last hunter-gatherers and the first farming communities in the south of the Iberian Peninsula and north of Morocco. Promontoria Monografias, Vol. 15 (pp. 89-98) University of Faro, Faro.

Linstädter, J., \& Kehl, M. (2012). The Holocene archaeological sequence and sedimentological processes at Ifri Oudadane, NE Morocco. Journal of Archaeological Science, 39(10), 3306-3323.

Linstädter, J., Aschrafi, M., Ibouhouten, H., Zielhofer, C., Bussmann, J., Deckers, K., et al. (2012). Flussarchäologie der Moulouya-Hochflutebene, NO-Marokko. Madrider Mitteilungen, 53, 1-84.

Linstädter, J., Broich, M., \& Weninger, B. (2016a). Defining the Early Neolithic of the Eastern Rif, Morocco-Spatial distribution, chronological framework and impact of environmental changes. Quaternary International, 472(Part B), 272282.

Linstädter, J., Kehl, M., Broich, J. A., \& López-Sáez. (2016b). Chronostratigraphy, site formation processes and pollen record of Ifri n'Etsedda, NE Morocco. Quaternary International, 410(Part A), 6-29.

López Castro, J. L., Ferjaoui, A., Mederos Martín, A., Martínez Hahnmüller, V., \& Ben Jerbania, I. (2016). La colonización fenicia inicial en el Mediterráneo Central: Nuevas excavaciones arqueológicas en Utica (Túnez). Trabajos de Prehistoria, 73(1), 68-89.

Lubell, D. (1984). Paleoenvironments and epi-paleolithic economies in the Maghreb (ca. 20,000 to 5000 BP). In J. D. Clark $\&$ S. A. Brandt (Eds.), From hunters to farmers: The causes and consequences of food production in Africa (pp. 41-56). Berkeley: University of California Press.

Lubell, D. (Ed.). (2016). Holocene Prehistory in the Télidjène Basin, Eastern Algeria: Capsian Occupations at Kef Zoura $D$ and Aïn Misteheyia. Oxford: Archaeopress.

Lubell, D., Feathers, J., \& Schwenninger, J. (2009). Post-Capsian occupation in the Eastern Maghreb: Implications of a revised chronological assessment for the adult burial at Aïn Misteheyia. Journal of African Archaeology, 7(2), 175-189.

Lucarini, G. (2009). Percorsi tra la Montagna e il Mare. Nuovi Dati sui Complessi Olocenici della Pianura della Gefara (Libia). Africa, 64, 433-447.

Lucarini, G. (2013). Was a transition to food production homogenous along the circum-Mediterranean littoral? A perspective on Neolithization research from the Libyan coast. In N. Shirai
(Ed.), Neolithisation of Northeastern Africa. Studies in Early Near Eastern production, subsistence, and environment 16 (pp. 149-174). Berlin: Ex Oriente.

Lucarini, G. (2014). Exploitation and management of wild grasses at Hidden Valley, Farafra Oasis. In B. E. Barich, G. Lucarini, M. A. Hamdan, \& F. A. Hassan (Eds.), From lake to sand. The archaeology of Farafra oasis, western desert, Egypt (pp. 345-367). Florence: All'Insegna del Giglio.

Lucarini, G., \& Radini, A. (2020). First direct evidence of wild plant grinding process from the Holocene Sahara: Use-wear and plant micro-residue analysis on ground stone tools from the Farafra Oasis, Egypt. Quaternary International, 555, 6684.

Lucarini, G., Radini, A., Barton, H., \& Barker, G. (2016). The exploitation of wild plants in Neolithic North Africa. Usewear and residue analysis on non-knapped stone tools from the Haua Fteah cave, Cyrenaica, Libya. Quaternary International, 410(Part A), 77-92.

Lucarini, G., Wilkinson, T., Crema, E. R., Palombini, A., Bevan, A., \& Broodbank, C. (2020). The MedAfriCarbon radiocarbon database and web application. Archaeological dynamics in Mediterranean Africa, ca. 9600-700 BC. Journal of Open Archaeology Data, 8, 1. https://doi.org/10.5334/joad.60.

Ludwig, E. (1942). The Mediterranean: Saga of a Sea. New York: Whittlesey House, McGraw-Hill Book Company.

Marshall, F., \& Weissbrod, L. (2011). Domestication processes and morphological change: Through the lens of the donkey and African pastoralism. Current Anthropology, 52(S4), 397-413.

Martínez Sánchez, R. M., Vera Rodríguez, J. C., Peña-Chocarro, L., Bokbot, Y., Pérez Jordà, G., \& Pardo-Gordó, S. (2018). The middle neolithic of Morocco's north-western Atlantic strip: New evidence from the El-Khil caves (Tangier). African Archaeological Review, 35(3), 417-442.

McBurney, C. B. M. (1967). The Haua Fteah (Cyrenaica) and the Stone Age of the South-East Mediterranean. Cambridge: Cambridge University Press.

Mercuri, A. M., Fornaciari, R., Gallinaro, M., Vanin, S., \& di Lernia, S. (2018). Plant behaviour from human imprints and the cultivation of wild cereals in Holocene Sahara. Nature Plants, 4(2), 71-81.

Merzoug, S., Kherbouche, F., Sehil, N., Chelli, R., \& Hachi, S. (2016). Faunal analysis of the Neolithic units from the Gueldaman Cave GLD1 (Akbou, Algeria) and the shift in sheep/goat husbandry. Quaternary International, 410, 43-49.

Mikdad, A. (1998). Étude préliminaire et datation de quelques éléments campaniformes du site de Kehf-el-Baroud, Maroc. Beitrâge zur Allgemeinen und Vergleichenden Archäologie, $18,243-252$.

Miniaoui, S. (2013). L'Archéologie funéraire Protohistorique en Tunisie: Répartition des nécropoles et état de la question. Revue Tunisienne d'Archéologie, 1, 55-76.

Mitchell, P. (2018). The donkey in human history: An archaeological perspective. Oxford: Oxford University Press.

Morales, J. (2018). The contribution of botanical macro-remains to the study of wild plant consumption during the Later Stone Age and the Neolithic of northwestern Africa. Journal of Archaeological Science: Reports, 22, 401-412.

Morales, J., Pérez-Jordà, G., Peña-Chocarro, L., Zapata, L., RuízAlonso, M., López-Sáez, J. A., et al. (2013). The origins of agriculture in North-West Africa: Macro-botanical remains 
from Epipalaeolithic and Early Neolithic levels of Ifri Oudadane (Morocco). Journal of Archaeological Science, 40(6), 2659-2669.

Morales, J., Mulazzani, S., Belhouchet, L., Zazzo, A., Berrio, L., Eddargach, W., et al. (2015). First preliminary evidence for basketry and nut consumption in the Capsian culture (ca. 10, 000-7500 BP): Archaeobotanical data from new excavations at El Mekta, Tunisia. Journal of Anthropological Archaeology, 37, 128-139.

Morales, J., Pérez-Jordà, G., Peña-Chocarro, L., Bokbot, Y., Vera, J. C., Martínez Sánchez, R. M., et al. (2016). The introduction of South-Western Asian domesticated plants in NorthWestern Africa: An archaeobotanical contribution from Neolithic Morocco. Quaternary International, 412, 96-109.

Mulazzani, S. (Ed.). (2013). Le Capsien de Hergla (Tunisie)_ Culture, environnement et économie. Frankfurt am Main: Africa Magna Verlag.

Nekkal, F., Linstädter, J., Aouraghe, H., \& Bougariane, B. (2015). Ifri Ouzabour: L'extrême extension de la culture cardiale sur le littoral méditerranéen sud (Rif oriental, Maroc). Bulletin de l'Institut Scientifique, Rabat, Section Sciences de la Terre, 37, $55-76$.

Nijboer, A. J., \& van der Plicht, J. (2008). The Iron Age in the Mediterranean: Recent radiocarbon research at the University of Groningen. In D. Brandherm, \& M. Trachsel (Eds.), A new dawn for the Dark Age? Shifting paradigms in Mediterranean Iron Age chronology - L'âge obscur se faitil jour de nouveau? Les paradigmes changeants de la chronologie de l'âge du Fer en Méditerranée. Proceedings of the XV World Congress (Lisbon 4-9 September 2006). BAR International Series 1871 (pp. 103-118). Oxford: Archaeopress.

O'Connor, D. (1990). The Nature of Tjemhu (Libyan) Society in the Later New Kingdom. In A. Leahy (Ed.), Libya and Egypt c. 1300-750 BC (pp. 29-113). London: SOAS Centre of Near and Middle Eastern Studies; Society for Libyan Studies.

Oueslati, A. (1995). Sur la richesse des côtes tunisiennes en industries lithiques préhistoriques: Signification chronostratigraphique et paléoenvironnementale des formes et dépôts hérités des 100000 dernières années. Revue Tunisienne de Géographie, 28, 173-197.

Ousmoï M. (1989). Application de la datation par thermoluminescence au Néolithique marocain. $\mathrm{PhD}$ thesis. Université Blaise Pascal, Clermont II, Clermont Ferrand.

Papi, E. (2019). Revisiting first millennium BC graves in NorthWest Morocco. In M. C. Gatto, D. Mattingly, N. Ray, \& M. Sterry (Eds.), Burials, migration and identity in the ancient Sahara and beyond (pp. 281-312). Cambridge: Cambridge University Press.

Pelling, R. (2005). Garamantian agriculture and its significance in a wider North African context: The evidence of the plant remains from the Fazzan project. The Journal of North African Studies, 10(3-4), 397-412.

Perrin, T., Dachy, T., Guéret, C., Lubell, D., Chaïd-Saoudi, Y., \& Green, W. (2020). Pressure knapping and the timing of innovation: New chrono-cultural data on prehistoric groups of the early Holocene in the Maghreb, northwest Africa. Radiocarbon, 62(2), 1-51.

Petit-Maire, N., Page, N., Laforest, P. (n.d.). World data center apaleoclimatology. The Sahara in the Holocene. $\mathrm{ftp}: / / \mathrm{ftp} . \mathrm{ncdc}$. noaa.gov/pub/data/paleo/radiocarbon/sahara.txt. Accessed 15 Sept 2020.

Rahmani, N. (2004). Technological and cultural change among the last hunter-gatherers of the Maghreb: The Capsian $(10,000$ 6000 BP). Journal of World Prehistory, 18, 57-105.

Rahmouni, O., Roussillot, C., \& Armanet, F. (1972). Algiers radiocarbon measurements II. Radiocarbon, 14(1), 1-5.

Ramos, J., Bernal Casasola, D., Raissouni, B., Zouak, M., El Khayari, A., Vijande Vila, E., et al. (2011). Informe de la campaña del año 2011 del proyecto de investigación 'Carta Arqueológica del norte de Marruecos'. Informes y Trabajos, 9, 508-545.

Recchia, G. (2011). Burial mound and 'specchie' in Apulia during the Bronze Age: Local developments and transadriatic connections. In E. Borgna \& S. Müller-Celka (Eds.), Ancestral landscapes: Burial mounds in the Copper and Bronze Ages (pp. 475-484). Lyon: Maison de l'Orient et de la Mediterranée Jean Pouilloux.

Rekacewicz, P. (1996). Atlas de Poche. Paris: Librairie Générale Française (revised in 2001).

Revenga, C., Murray, S., Abramovitz, J., \& Hammond, A. (1998). Watersheds of the world: Ecological value and vulnerability. Washington DC: World Resources Institute.

Rognon, P. (1987). Late Quaternary climatic reconstruction for the Maghreb (North Africa). Palaeogeography, Palaeoclimatology, Palaeoecology, 58, 11-34.

Rossel, S., Marshall, F., Pilgram, T., Adams, M. A., \& O’Connor, D. (2008). Domestication of the donkey: Timing, processes, and indicators. PNAS, 105(10), 3715-3720.

Roubet, C. (1979). Économie pastorale préagricole en Algérie orientale: Le Néolithique de Tradition Capsienne. Exemple: L'Aurès. Paris: Éditions du Centre National de la Recherche Scientifique.

Rubinos, A. (2014). Approach to the absolute chronology of the human settlement in the Oukaïmeden valley (High Atlas, Morocco). Some comments. Complutum, 25(2), 111-121.

Ruiz-Gálvez, M. L., de la Peña, P., de Torres, J., Bokbot, Y., Madi, M., Collado, H., et al. (2013). Cuarta campaña de campo en Oukaïmeden (Alto Atlas) y nuevos datos sobre la gestión de recursos críticos en un tipo de valle alpino en la Prehistoria. Informes y Trabajos, 9, 470-489.

Saliège, J., Magnani, G., \& Mulazzani, S. (2013). Datations 14C de la rammadiya SHM-1. In S. Mulazzani (Ed.), Le Capsien de Hergla (Tunisie) - Culture, environnement et économie (pp. 145-150). Frankfurt am Main: Africa Magna Verlag.

Sam, Y. (2020). African origins of modern asses as seen from paleontology and DNA: What about the Atlas wild ass? Geobios, 58, 73-84.

Sanmartí, J., Kallala, N., Belarte, M. C., Ramon, J., Maraoui Telmini, B., Jornet, R., et al. (2012). Filling gaps in the protohistory of the eastern Maghreb: The Althiburos archaeological project (E1 Kef, Tunisia). Journal of African Archaeology, 10(1), 21-44.

Schuhmacher, T. X. (2017). Ivory exchange networks in the Chalcolithic of the Western Mediterranean. In M. Bartelheim, P. Bueno Ramírez, \& M. Kunst (Eds.), Key resources and sociocultural developments in the Iberian Chalcolithic. RessourcenKulturen Band 6 (pp. 291-312). Tubingen: Tübingen Library Publishing. 
Searight, S. (2004). The prehistoric rock art of Morocco: A study of its extension, environment and meaning, BAR International Series 1310. Oxford: Archaeopress.

Simpson, F. (2000). Evidence for Late Bronze Age Libyan culture at the New Kingdom Egyptian fortress of Zawiyet Umm elRakham. In A. McDonald \& C. Riggs (Eds.), Current Research in Egyptology 2000. British Archaeological Reports, International Series 909 (pp. 97-102). Oxford: Archaeopress.

van der Plicht, J., Bruins, H. J., \& Nijboer, A. J. (2009). The Iron Age around the Mediterranean: A high chronology perspective from the Groningen radiocarbon database. Radiocarbon, 51(1), 213-242.

van der Veen, M. (2006). Food and farming in the Libyan Sahara. In D. Mattingly, S. McLaren, E. Savage, Y. Al-Fasatwi, \& K. Gadgood (Eds.), The Libyan Desert: Natural resources and cultural heritage. Society for Libyan Studies Monograph 6 (pp. 171-178). London: Society for Libyan Studies.

van der Veen, M. (2010). Plant remains from Zinkekra: Early evidence for oasis agriculture. In D. J. Mattingly (Ed.), The Archaeology of Fazzan III. Excavations of C. M. Daniels (pp. 489-519). London: Society for Libyan Studies / Tripoli: Department of Antiquities.

Vermeersch, P. M., Linseele, V., Marinova, E., Van Neer, W., Moeyersons, J., \& Rethemeyer, J. (2015). Early and middle Holocene human occupation of the Egyptian Eastern Desert: Sodmein Cave. African Archaeological Review, 32, 465503.

Vernet, R., \& Aumassip, G. (1992). Le Sahara et ses marges. Paléoenvironnements et occupation humaine à l'Holocène. Inventaire des datations $14 C$. Meudon: CNRS.

Vijande-Vila, E., Cantillo-Duarte, J. J., Ramos-Muñoz, J., BernalCasasola, D., Domínguez-Bella, S., Cruz, S. A., et al. (2019). The occupation of Benzú Cave (Ceuta) by Neolithic and Bronze Age Societies. African Archaeological Review, 36, 317-338.

Vives-Ferrándiz, J., Cañete, C., Gòmez Bellard, C., LópezBertran, M., \& Roman, D. (2010). La primera ocupación del sector 2.3: Arquitectura y Materiales. In C. Aranegui \& H. Hassini (Eds.), Lixus-3. Area suroeste del sector monumental [cámaras Montalbán] 2005-2009 (pp. 69-98). Valencia: Universidad de Valencia.

Wasylikowa, K. (2001). Site E-75-6: Vegetation and subsistence of the Early Neolithic at Nabta Playa, Egypt, reconstructed from charred plant remains. In F. Wendorf, R. Schild, \& Associates (Eds.), Holocene Settlement of the Egyptian Sahara. Volume 1: The Archaeology of Nabta Playa (pp. 544-591). New York: Kluwer Academic/Plenum Publishers.

Wendorf, F., Schild, R., \& Associates (Eds.). (2001). Holocene Settlement of the Egyptian Sahara. Volume 1: The Archaeology of Nabta Playa. New York: Kluwer Academic/Plenum Publishers.

Wengler, L. (1985-1986). Contribution à la préhistoire et à la chronostratigraphie du Quaternaire récent au Maroc oriental. Travaux de la Mission Préhistorique Paléontologique Française au Maroc, 1, 131-174.

Wengler, L., \& Vernet, J. (1992). Vegetation, sedimentary deposits and climates during the Late Pleistocene and Holocene in eastern Morocco. Palaeogeography, Palaeoclimatology, Palaeoecology, 94, 141-167.

Wengler, L., Vernet, J., \& Michel, P. (1994). Evénements et chronologie de l'Holocène en milieu continental au Maghreb. Les données du Maroc oriental. Quaternaire, 5(3), 119-134

Wolf, A. T., Natharius, J. A., Danielson, J. J., Ward, B. S., \& Pender, J. K. (1999). International river basins of the world. International Journal of Water Resources Development, 15(4), 387-427.

Zerai, K. (2009). Chronostratigraphy of Holocene alluvial archives in the Wadi Sbeïtla basin (central Tunisia). Géomorphologie: Relief, processus, environnement, 15(4), 271-286.

Publisher's Note Springer Nature remains neutral with regard to jurisdictional claims in published maps and institutional affiliations. 